\title{
Arctotheca prostrata (Asteraceae: Arctotideae), a SOUth African speCies nOW PRESEnt in MeXico
}

\author{
Oscar Hinojosa-Espinosa ${ }^{1,2,3}$ y José LUIS VilLaseñor ${ }^{1}$ \\ 'Instituto de Biología, Departamento de Botánica, Universidad Nacional Autónoma de México, México, D. F. \\ ${ }^{2}$ Facultad de Ciencias, Departamento de Biología Comparada, Universidad Nacional Autónoma de México, \\ México D.F. \\ ${ }^{3}$ Corresponding author: ohe@ciencias.unam.mx
}

\begin{abstract}
Arctotheca prostrata is a South African species that has been introduced in other parts of the world, such as California and Australia. Here we report the presence of A. prostrata for the first time in Mexico. To date we have detected the species in nine sites south of Mexico City. The species shows weedy tendencies at each site. It is possible that A. prostrata arrived to Mexico through horticulture and later escaped from cultivation. This species needs to be included in the list of Mexican prohibited weeds, thus permitting the implementation of preventive strategies to avoid its spreading in the country.
\end{abstract}

Key words: Arctotidinae, escaped from cultivation, introduced weeds, South African weeds.

Resumen: Arctotheca prostrata es una especie sudafricana que se encuentra introducida en otras partes del mundo, tales como California y Australia. En este artículo se da a conocer por primera vez la presencia de A. prostrata en México. Hasta el momento la especie se ha detectado en nueve sitios al sur de la Ciudad de México. En cada localidad, la especie se comporta como maleza. Es posible que A. prostrata haya llegado a México a través de la horticultura y posteriormente escapara de cultivo. Por último, se considera necesario incluir esta especie en la lista de malezas cuarentenarias para México y de esta manera establecer estrategias preventivas para evitar su propagación por el país.

Palabras clave: Arctotidinae, escapada de cultivo, malezas introducidas, malezas sudafricanas.

$A$ rctotheca Vaill., a genus of the tribe Arctotideae, subtribe Arctotidinae (Asteraceae), comprises five species of decumbent or rosulate herbs (Mahoney and McKenzie, 2013). The species of Arctotheca share mostly lobed-pinnatifid leaves, radiate, solitary capitula, sterile ray florets, hermaphrodite and fertile disc florets, obovoid-elliptic, tangentially flattened, 4-5 ribbed, and villous or glabrous cypselae, and a pappus that is usually composed of a whorl of scales shorter than the cypselae or absent (Bremer, 1994; McKenzie et al., 2005; Karis, 2007).

Arctotheca occurs natively in South Africa and Mozambique (Bremer, 1994; Karis, 2007); however, weedy species such as Arctotheca calendula (L.) Levyns and A. prostrata (Salisb.) Britten, occur as introduced elsewhere. In California, A. calendula is considered a highly invasive weed and listed by the California Exotic Pest Plant Council as a weed with the potential to spread explosively (Mahoney and McKenzie, 2008). In Australia, this species is also invasive, found widespread on pastoral and agricultural lands
(Karis et al., 2009). In addition, Deluchi and Hurrel (2013) report that $A$. calendula is introduced and weedy in Europe, Palestine, Japan, New Zealand, Chile, and Argentina. In the case of A. prostrata, this species is exotic in California and according to Mahoney and McKenzie (2008), is an infertile perennial that spreads vigorously by stolons along roadsides and other disturbed sites. In this paper, we report the first record of A. prostrata in Mexico. This is also the first record of the genus Arctotheca in the country and the first record of a truly weedy species of Arctotideae in Mexico.

\section{Materials and methods}

We detected an unknown Asteraceae weed in a disturbed lawn near the School of Sciences, on the campus of the Universidad Nacional Autónoma de México (UNAM), south of Mexico City (Table 1). We subsequently collected samples and prepared herbarium specimens that were deposited in the collection of the National Herbarium of Mexico (MEXU), 


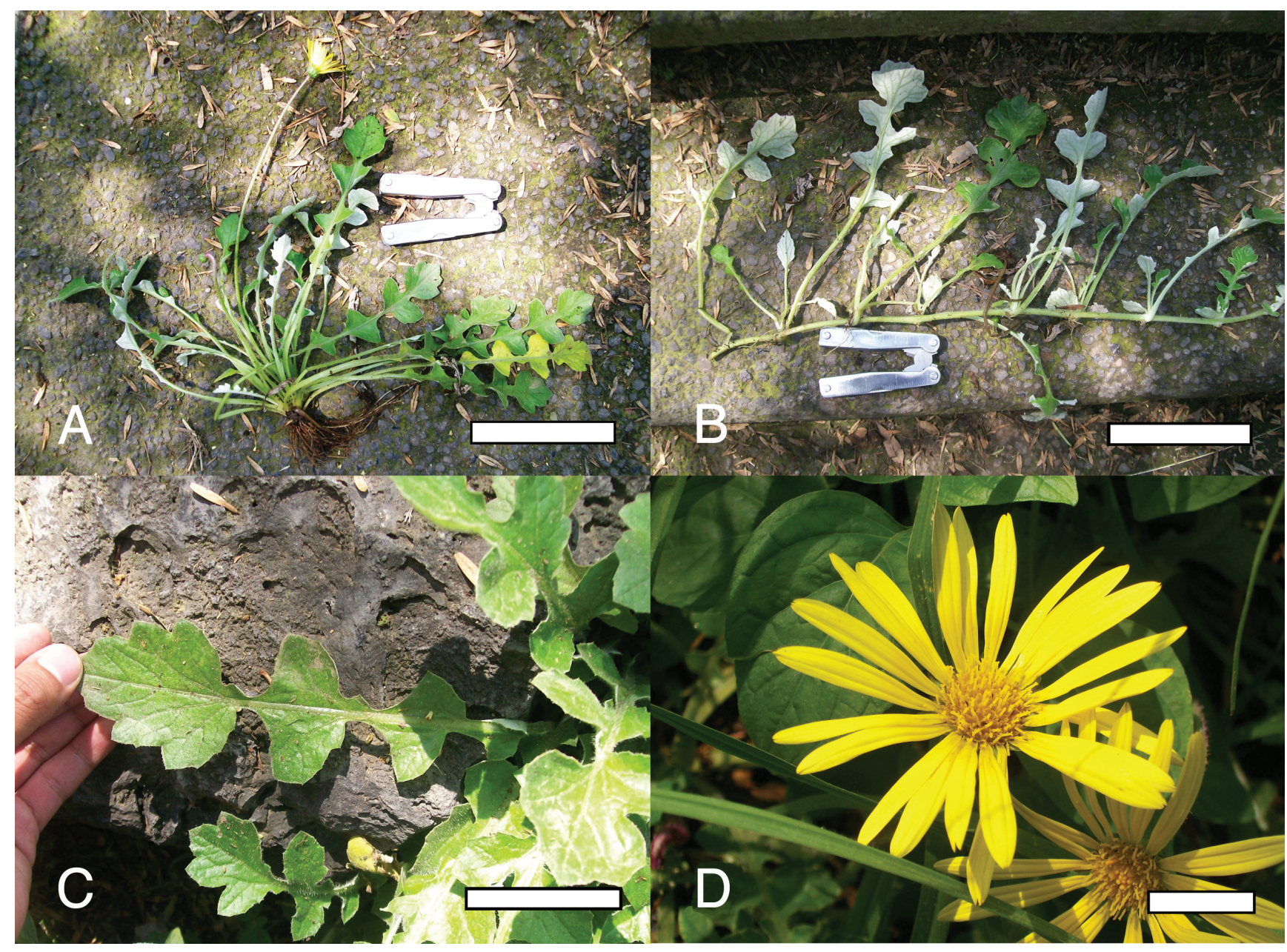

Figure 1. Morphology of Arctotheca prostrata. A) rosulate scapiform habit. White bar $=7 \mathrm{~cm}$. B) a stolon with young rosettes at nodes. White bar $=7 \mathrm{~cm}$. C) lyrate-pinnatifid leaves. White bar $=2 \mathrm{~cm}$. D) a radiate head. White bar $=2 \mathrm{~cm}$. All pictures taken near School of Sciences, UNAM (see Table 1). Color photographs and additional photographs are available from the corresponding author.

as Hinojosa-Espinosa 580-1-5. By using the works of Karis (2007) and Mahoney and Mckenzie (2013), we determined the material as Arctotheca prostrata. Finally, we described the species from fresh and herbarium materials.

\section{Results}

Arctotheca prostrata (Salisb.) Britten, J. Bot. 54: 61. 1916. Perennial scapiform herbs, 5-52 cm high, somewhat fleshy, provided with long stolons rooting at nodes. Leaves alternate, aggregated in a basal rosette, lobulated to lyrate-pinnatifid, petiolate, 5-30 cm long, conspicuously discolorous, green and hirsute on the adaxial surface, white and wooly on the abaxial surface. Heads solitary, radiate, showy, 2$7 \mathrm{~cm}$ across when fresh; peduncles $5-30 \mathrm{~cm}$ long, usually provided with hirsute purple hairs. Involucre campanulate to hemispheric, $1-2 \mathrm{~cm}$ diameter; involucral bracts distinct, graduated in 4-6 series. Ray florets neuter, 15-25, deciduous, ligules oblong, with 3 apical teeth, $2-5 \mathrm{~cm}$ long, $0.3-$
$0.6 \mathrm{~cm}$ wide, adaxially yellow, abaxially yellow and faintly gray-greenish or purple tinged, four-veined. Disk florets hermaphrodite and sterile, ca. 50, corollas tubular, with 5 teeth, yellow. Style cylindrical, thickened apically, minutely bifid, with a ring of sweeping hairs well below the bifurcation. Cypselas obovoid, compressed, whitish, not maturing, densely woolly to glabrous. Pappus, a whorl of 7-9 scarious scales, $0.5 \mathrm{~mm}$ long. Receptacle plane, alveolate, glabrous, epaleate (Figure 1).

Although initially the species was observed in one site near the School of Sciences, routine walks across the campus of UNAM have revealed that the species is more widespread than previously thought (Table 1 ). So far, we have observed the species in at least eight different sites at the campus. Furthermore, we also have observed the species in two lawns at the National Park "Bosque de Tlalpan", which is located approximately five kilometers south of UNAM. In each locality, the species is weedy and shows invasive tendencies through the production of stolons. 


\section{Discussion}

Members of the South African tribe Arctotideae are practically unknown in Mexico; however, they can be recognized by their alternate leaves, usually radiate and heterogamous heads and especially by their style, which is distally dilated and has a ring of sweeping hairs well below the bifurcation (Bremer, 1994; Karis, 2007). The Arctotidinae are characterized by free involucral bracts and four-veined ligules with three apical teeth. Within this subtribe, the genus Arctotheca is distinguished mainly by its neuter and sterile ray florets and by its scapiform and rosulate habit (Karis, 2007). The species A. prostrata is very similar to A. calendula; however the latter is a fertile annual rosulate herb without stolons (although sometimes it has decumbent stems that rarely root at nodes), its rays are shorter (mostly $0.6-1.5 \mathrm{~cm}$ ), and its disc corollas are not completely yellow but proximally yellow and distally green to black (Mahoney and Mckenzie, 2013).

It is possible that $A$. prostrata arrived to Mexico through cultivation and later escaped. The presence of the species in lawns, grasslands, and gardens in the campus of UNAM and in the national park "Bosque de Tlalpan" suggests that the species was first introduced as ornamental and then started to spread, as occurred in California (Mahoney and Mckenzie, 2013). It is worth noting that the only additional member of Arctotideae recorded for Mexico is Gazania linearis (Thunb.) Druce, which is a popular ornamental species in central Mexico, and apparently its records only come from cultivated plants (Villaseñor et al., 2012). Similarly, all representatives of Arctotideae currently registered for the United States are considered introduced through horticulture (Mahoney and Mckenzie, 2008). On the other hand, another possibility is that dormant stolons of $A$. prostrata were introduced with soil or blocks of grass used for gardens and lawns. This would explain how the species has become scattered in lawns and grasses without the production of viable seeds.

We do not discard the possibility that A. prostrata is more widespread but has so far gone unnoticed. The species is rel- atively easy to overlook because at first glance it resembles the dandelion (Taraxacum officinale F.H. Wigg.), which is widespread in Mexico (Villaseñor et al., 2012); however, the dandelion has concolored leaves and all of its florets are ligulate, among other characters. In addition, the scarce knowledge of the tribe Arctotideae in Mexico hinders the recognition of its members.

The presence of Arctotheca prostrata in Mexico City shows its ability to thrive in a wide range of environmental conditions. According to Karis et al. (2009), many Arctotidinae species naturalized abroad are present principally in regions with Mediterranean-type climate. However, in Mexico City the climate is temperate subhumid $(\mathrm{Cw})$ (JáureguiOstos, 2000). In addition, the altitudinal range at which $A$. prostrata grows in Mexico (2267-2326 m) is much higher than that at which it grows in California $(<400 \mathrm{~m}$ ) (Mahoney and Mckenzie, 2013).

Finally, we consider it necessary to include A. prostrata in the Mexican list of prohibited weeds (Diario Oficial de la Federación, 2000), and thus establish preventive strategies to avoid its spreading in the country beyond the localities identified until now. The species is undesirable because it has a high invasive potential and due to its presence in a national park (Bosque de Tlalpan) and close to an ecological reserve housed by UNAM, the "Reserva Ecológica del Pedregal de San Ángel (REPSA)". These two natural areas are fragments of a formerly larger ecosystem that has been deteriorating rapidly due to the accelerated expansion of Mexico City (Castillo-Argüero et al., 2009). The REPSA, which has considerable floristic diversity, currently suffers the invasion of species that were not present before and that threaten its native species and the dynamics of the ecological reserve (Castillo-Argüero et al., 2009).

\section{Acknowledgments}

We thank the authorities and staff of the National Herbarium (MEXU) of the Institute of Biology (UNAM) for their assistance in several activities of this research. We

Table 1. Localities in which Arctotheca prostrata has been found to date in southern Mexico City.

\begin{tabular}{|c|c|c|c|c|}
\hline Locality & Geographical coordinates & Altitude (m) & Habitat & Population \\
\hline Bosque de Tlalpan, National Park & $19^{\circ} 19^{\prime} 48^{\prime \prime} \mathrm{N}, 99^{\circ} 11^{\prime} 35^{\prime \prime} \mathrm{W}$ & 2,326 & Disturbed grass & Wide colony \\
\hline Institute of Chemistry, UNAM & $19^{\circ} 19^{\prime} 47^{\prime \prime} \mathrm{N}, 99^{\circ} 10^{\prime} 52^{\prime \prime} \mathrm{W}$ & 2,284 & Garden lawn & Several rosettes \\
\hline Institute of Ecology, UNAM & $19^{\circ} 18^{\prime} 57^{\prime \prime} \mathrm{N}, 99^{\circ} 11^{\prime} 33^{\prime \prime} \mathrm{W}$ & 2,326 & Garden lawn & Wide colony \\
\hline Near School of Medicine, UNAM & $19^{\circ} 20^{\prime} 03^{\prime \prime} \mathrm{N}, 99^{\circ} 10^{\prime} 45^{\prime \prime} \mathrm{W}$ & 2,267 & Garden & Few rosettes \\
\hline Near School of Sciences, UNAM & $19^{\circ} 19^{\prime} 31^{\prime \prime} \mathrm{N}, 99^{\circ} 10^{\prime} 41^{\prime \prime} \mathrm{W}$ & 2,292 & Disturbed grass & Several rosettes \\
\hline Near Olympic Stadium, UNAM & $19^{\circ} 20^{\prime} 04^{\prime \prime} \mathrm{N}, 99^{\circ} 11^{\prime} 24^{\prime \prime} \mathrm{W}$ & 2,298 & Median strip grass & Several rosettes \\
\hline School of Psychology, UNAM & $19^{\circ} 20^{\prime} 11^{\prime \prime} \mathrm{N}, 99^{\circ} 11^{\prime} 16^{\prime \prime} \mathrm{W}$ & 2,284 & Two lawns & Several rosettes \\
\hline UNAM's Supermarket & $19^{\circ} 19^{\prime} 19^{\prime \prime} \mathrm{N}, 99^{\circ} 10^{\prime} 34^{\prime \prime} \mathrm{W}$ & 2,279 & Lawn & Wide colony \\
\hline Universum Museum, UNAM & $19^{\circ} 18^{\prime} 39^{\prime \prime} \mathrm{N}, 99^{\circ} 10^{\prime} 53^{\prime \prime} \mathrm{W}$ & 2,317 & Disturbed grass & Few rosettes \\
\hline
\end{tabular}


also thank Enrique Ortiz for taking and providing photographs of Arctotheca prostrata. Likewise, we thank the two anonymous reviewers for their helpful suggestions and corrections and to David S. Gernandt for reviewing and correcting the English.

\section{Literature cited}

Bremer K. 1994. Arctotideae. In: Bremer K. Ed. Asteraceae: Cladistics \& Classification, pp. 246-262, Timber Press, Portland.

Castillo-Argüero S., Martínez Orea Y., Meave J.A., HernándezApolinar M., Nuñez-Castillo O., Santibañez-Andrade G. and Guadarrama-Chávez P. 2009. Flora: susceptibilidad de la comunidad a la invasión de malezas nativas y exóticas. In: Lot A. and Cano-Santana Z. Eds. Biodiversidad del Ecosistema del Pedregal de San Ángel, pp. 107-133, Universidad Nacional Autónoma de México, México, D.F.

Diario Oficial de la Federación. 2000. NOM-043-FITO-1999: Especificación para prevenir la introducción de malezas cuarentenarias a México, México.

Deluchi G. and Hurrell J.A. 2013. Arctotheca. In: Hurrell J.A. Ed. Flora Rioplatense. Sistemática, Ecología y Etnobotánica de las Plantas Vasculares Rioplatenses: II. Dicotiledóneas, pp. 67-69, Sociedad Argentina de Botánica, Buenos Aires.

Jáuregui-Ostos E. 2000. El clima de la Ciudad de México. Instituto de Geografía, Universidad Nacional Autónoma de México/ Plaza y Valdés, Mexico, D.F.

Karis P.O. 2007. Arctotideae. In: Kadereit J.W. and Jeffrey C. Eds.
The Families and Genera of Vascular Plants, Vol. VIII: Flowering Plants Eudicots, Asterales, pp. 200-207, Springer, Heidelberg.

Karis P.O., Funk V.A., McKenzie R.J., Barker N.P. and Chan R. 2009. Arctotideae. In: Funk V.A., Sussana A., Stuessy T. and Bayer R. Eds. Systematics, Evolution, and Biogeography of Compositae, pp. 385-410, International Association for Plant Taxonomy (IAPT), Vienna.

Mahoney A.M. and McKenzie R.J. 2008. Notes on two southern African Arctotis species (Arctotideae: Asteraceae) growing in California. Madroño 55:244-247.

Mahoney A.M. and McKenzie R.J. 2013. Arctotheca. In: Jepson Flora Project. Eds. Jepson eFlora. <http://ucjeps.berkeley.edu/ cgi-bin/get_IJM.pl?tid=82568> (accessed on Jul 29 2014).

McKenzie, R.J., Samuel J., Muller, E.M., Skinner A.K.W., and Barker N.P. 2005. Morphology of Cypselae in Subtribe Arctotidinae (Compositae-Arctotideae) and its taxonomic implications. Annals of the Missouri Botanical Garden 92:569-594.

Villaseñor J.L., Ortiz E., Hinojosa-Espinosa O. and SeguraHernández G. 2012. Especies de la Familia Asteraceae Exóticas a la Flora de México. Secretaria de Agricultura Ganaderia, Desarrollo Rural, Pesca y Alimentación (SAGARPA), Servicio Nacional de Sanidad, Inocuidad y Calidad Agroalimentaria (SENASICA), Consejo Nacional Consultivo Fitosanitario (CONAFI), Instituto de Biología de la Universidad Nacional Autónoma de México, and Asociación Mexicana de la Ciencia de la Maleza (ASOMECIMA), México D.F.

Received: September 5th, 2014

Accepted: December 11th, 2014 